\title{
KAJIAN SIFAT FISIK A ULTISOL PADA LAHAN BUDIDAYA NENAS DENGAN BERBAGAI POLA ROTASI DI PT. GREAT GIANT PINEAPPLE TERBANGGI BESAR, LAMPUNG
}

\section{(STUDY OF THE PHYSICAL PROPERTIES OF ULTISOLS ON PINEAPPLE CULTIVATION LAND WITH VARIOUS ROTATION PATTERN AT PT GREAT GIANT PINEAPPLE TERBANGGI BESAR, LAMPUNG)}

\author{
Angga Suseno ${ }^{1)}$, AZ Purwono Budi Santoso ${ }^{2) *(}$ dan Susila Herlambang $^{2)}$ \\ ${ }^{1)}$ Prodi Agroteknologi, Universitas Pembangunan Nasional Veteran Yogyakarta \\ 2) Prodi Ilmu Tanah, Universitas Pembangunan Nasional Veteran Yogyakarta \\ ${ }^{*}$ Corresponding author E-mail: pbudisant@yahoo.com
}

\begin{abstract}
Ultisol is one of the highly-weathered soil types. This soil has high clay content in subsoil. Based on the physical aspects, Lampung Ultisols have less solid soil structure, slow permeability, poor porosity, less stable aggregate and high bulk density. Plant rotation is an alternative in improving the physical properties of Ultisol soil at PT. Great Giant Pineapple. By doing crop rotation, it is hoped that it can provide a large impact to improve the physical properties of Ultisol. This study aims to examine the physical properties of Ultisol in the rotation pattern of pineapple-banana, pineapple-pineapple and the pineapple-cassava. The study design used a Randomized Block Design (RBD) and location determination using a purposive method. The mean of difference between treatments for each parameter was tested according to Duncan Multiple Range Test (DMRT) with a level of 0,05. Taking soil samples using a diagonal pattern with a depth of 0-40 $\mathrm{cm}$. The treatment by pineapple-banana rotation pattern is the best treatment whit producing granular structure, with strong degrees, bulk density $1,48 \mathrm{~g} / \mathrm{cm} 3$, soil strength $0,78 \mathrm{~kg} / \mathrm{cm} 2$, porosity $43,62 \%$. Crop rotation by pineapple-banana rotation pattern, is a good technique in improving soil physical properties at PT. Great Giant Pineapple.
\end{abstract}

\section{Keywords: plant rotation, soil physical properties, Ultisol}

\begin{abstract}
ABSTRAK
Ultisol merupakan salah satu jenis tanah yang mengalami pelapukan lanjut. Tanah ini memiliki kandungan lempung yang tinggi pada bagian sub soil. Berdasarkan aspek fisika, Ultisol Lampung memiliki struktur tanah yang kurang mantap, permeabilitas yang lambat, porositas yang buruk, agregat kurang stabil dan bobot isi tinggi. Rotasi tanaman merupakan alternatif dalam memperbaiki sifat fisika tanah Ultisol di PT. Great Giant Pineapple. Dengan dilakukannya rotasi tanaman diharapkan mampu memberikan dampak yang besar untuk memperbaiki sifat fisika tanah Ultisol. Penelitian ini bertujuan untuk mengkaji sifat fisika tanah Ultisol pada pola rotasi nenas-pisang, nenas-nenas dan nenas-singkong. Rancangan penelitian menggunakan Rancangan Acak Kelompok (RAK) dan penentuan lokasi dengan menggunakan metode purposif. Beda rerata antar perlakuan untuk setiap parameter di uji menurut Duncan Multiple Range Test (DMRT) dengan jenjang 0,05 . Pengambilan sampel tanah menggunakan ring sampler dengan pola diagonal dengan kedalaman 0-40 cm. Perlakuan dengan pola rotasi nenas-pisang merupakan perlakuan terbaik dengan menghasilkan struktur granular, dengan derajat kuat, berat volume 1,48 $\mathrm{g} / \mathrm{cm} 3$, kekuatan tanah $0,78 \mathrm{~kg} / \mathrm{cm} 2$, porositas $43,62 \%$. Rotasi tanaman dengan pola rotasi nenas-
\end{abstract}


pisang, merupakan teknik yang baik dalam memperbaiki sifat fisika tanah di PT. Great Giant Pineapple.

Kata Kunci: rotasi tanaman, sifat fisika tanah, Ultisol

\section{PENDAHULUAN}

Lampung merupakan salah satu jenis tanah yang mengalami pelapukan yang cukup lanjut. Ultisol Lampung memiliki lempung yang tinggi pada lapisan sub soil. Pada umumnya Ultisol Lampung memiliki sifat fisika tanah yang buruk seperti struktur yang kurang mantap, permeabilitas yang lambat, agregat kurang stabil dan bobot isi yang tinggi (Utomo, 1994) hal tersebut diperparah dengan sistem tanam yang di terapkan di PT. Great Giant Pineapple pada lahan seluas 32.000 ha hanya ditanami nenas secara monokultur. Hal tersebut dilakukan untuk mengejar hasil produksi tanaman nenas, dari sistem tanam monokultur mengakibatkan tanah menjadi keras. Pada tahun 2017 mulai dilakukan rotasi tanaman dengan dua komoditas yaitu pisang dan singkong dengan pola rotasi nenaspisang dan nenas-singkong tetapi sebagian besar lahan masih menggunakan sistem monokultur. Dilakukan rotasi tanaman bertujuan untuk memperbaiki sifat fisika Ultisol. Dipilih dua komoditas yang digunakan untuk rotasi yaitu pisang dan singkong. Dipilih tanaman pisang karena pada tanaman pisang mempunyai perakaran yang panjang dan distribusi akar jauh sehingga dapat memecah agregat tanah selain itu pada perakaran tanaman pisang banyak terdapat rambut akar yang akan menembus celah antar partikel tanah, hal tersebut dapat mengikat antar partikel tanah menjadi bentuk yang lebih mantap selain itu pada tanaman pisang terdapat bonggol pisang dimana pada bonggol pisang tersebut banyak terdapat MOL (mikroorganisme lokal) dimana mikroorganisme yang mendominasi adalah Bacillus sp, Aeromonas sp dan Aspergillus sp yang mampu merombak biomassa menjadi bahan organik (Suhastyo, 2011). Tanaman singkong dipilih karena pada umbi singkong terdapat banyak cendawan yang miselianya yang berupa benang-benang akan berfungsi sebagai perajut antar partikel tanah. Dengan struktur tanah yang baik maka akan mampu menurunkan nilai berat volume, menurunkan nilai ketahanan tanah, meningkatkan porositas, meningkatkan permeabilitas tanah dan meningkatkan aerasi tanah. Selain dilakukan rotasi tanaman juga dilakukan pengembalian biomassa pada tanaman pisang dan singkong yang memberikan sumbangan $\mathrm{C}$ organik yang cukup besar. Dengan dilakukannya rotasi tanaman diharapkan mampu memberikan kontribusi yang tinggi terhadap kualitas tanah seperti mampu meningkatkan bahan organik, memperbaiki struktur tanah, memperbaiki agregasi dan keseimbangan pori dengan efek positif pada infiltrasi dan kelembaban tanah.

\section{BAHAN DAN METODE}

Metode yang digunakan dalam penelitian ini adalah survey dan purposif. Metode survey digunakan untuk mendapatkan keterangan atau pengumpulan data dengan mengadakan penjelajahan dan pengamatan langsung dilokasi penelitian serta mencari data pendukungnya. Pengamatan dimulai dengan menentukan lokasi penelitian yang didasarakan pada pola rotasi tanaman di PT. Great Giant Pineapple. Selanjutnya melakukan penjelajahan pada areal perkebunan nenas untuk mengenal kondisi lapangan, terutama di lahan dengan pola rotasi nenas-pisang, nenas-nenas dan nenas-singkong dan 
untuk metode purposif digunakan untuk penentuan lokasi pengambilan sampel tanah yang berdasarkan rotasi tanaman yaitu lahan di lokasi $509 \mathrm{C}$ dengan perlakuan rotasi tanaman nenas-pisang, lokasi $520 \mathrm{C}$ dengan perlakuan rotasi tanaman nenas-nenas dan lokasi 542 E dengan perlakuan rotasi tanaman nenas-singkong. Pengambilan sampel tanah menggunakan ring sampler dengan metode purposif pada masing-masing lokasi diambil 5 sampel, sehingga jumlah keseluruhan terdapat 15 titik sampel pada kedalaman yang sama yaitu $0-40 \mathrm{~cm}$.

\section{HASIL DAN PEMBAHASAN}

Hasil analisis tekstur tanah menunjukan geluh lempung pasiran. Persentase pasir di setiap perlakuan cukup besar lebih dari 50\% hal ini disebabkan karena bahan induk yang berasal dari batuan granit yang kaya akan mineral kuarsa, seperti yang dijelaskan Hardjowigeno (2010). Tekstur Ultisol bervariasi dan dipengaruhi oleh bahan induk tanah. Ultisol berbahan induk granit yang kaya akan mineral kuarsa umumnya memiliki tekstur yang kasar seperti geluh lempung pasiran, sedangkan Ultisol dari batu kapur, batuan andesit dan tufa cenderung mempunyai tekstur yang halus seperti lempung. Tingginya curah hujan di PT. Great Giant Pineapple memberikan pengaruh yang besar terhadap tekstur tanah di lapisan top soil, hal tersebut dikarenakan air hujan akan membantu mempercepat mobilisasi fraksi lempung. Lempung akan berpindah kebawah akibat proses eluviasi (perpindahan lempung ke bagian sub soil) kemudian akan tertimbun di bagian sub soil (iluviasi) sehingga bagian top soil hanya tersisa fraksi pasir.

Tabel 1. Tekstur tanah pada pola rotasi nenas-pisang, nenas-nenas dan nenas - singkong

\begin{tabular}{cccrrrl}
\hline \multirow{2}{*}{ No } & \multirow{2}{*}{ Perlakuan } & \multirow{2}{*}{ Kedalaman } & Pasir & Debu & Lempung & \multirow{2}{*}{ Tekstur } \\
\cline { 4 - 5 } & & & $\%$ & & GLP \\
\hline 1 & $\mathrm{~N}-\mathrm{P}$ & $0-40$ & 66,04 & 7,32 & 26,64 & GLP \\
2 & $\mathrm{~N}-\mathrm{N}$ & $0-40$ & 66,86 & 3,82 & 29,32 & GLP \\
3 & $\mathrm{~N}-\mathrm{S}$ & $0-40$ & 73,18 & 5,82 & 21,00 & \\
\hline
\end{tabular}

Keterangan: $\mathrm{N}-\mathrm{P}=$ Pola rotasi tanaman nenas-pisang; $\mathrm{N}-\mathrm{N}=$ Pola rotasi tanaman nenasnenas; $\mathrm{N}-\mathrm{S}=$ Pola rotasi tanaman nenas-singkong; $G L P=$ Geluh Lempung Pasiran

Hasil pengamatan struktur tanah menunjukan bahwa pola rotasi yang menghasilkan struktur yang sesuai bagi pertumbuhan tanaman adalah pola rotasi N-P dan N-S. Hal tersebut karena pada tanaman pisang mempunyai perakaran yang panjang sehingga distribusi perakaran jauh. Dengan perakaran yang panjang dan distribusi akar jauh maka perakaran tanaman pisang akan lebih mudah untuk menembus tanah sehingga dapat memecah agregat tanah dan pada perakaran tanaman pisang banyak terdapat rambut akar yang akan menembus celah antar partikel tanah hal tersebut dapat mengikat antar partikel tanah menjadi bentuk yang lebih mantap.

Pada pola rotasi N-S yang berperan besar untuk menciptakan struktur tanah yang sesuai untuk pertumbuhan tanaman adalah pada tanaman singkong terdapat banyak vegetasi rumput dimana pada vegetasi tersebut terdapat fungi, hal tersebut sesuai dengan pendapat Arsyad et al.., (1975) yang menjelaskan yang berperan dalam pemantapan ataupun peningkatan agregat mikro menjadi agregat makro di antaranya tumbuhan rendah 
seperti fungi. Peningkatan populasi fungi akan meningkatkan kemampuan agregasi partikel-partikel penyusun tanah. Mikroba dan miselianya, yang berupa benang-benang, akan berfungsi sebagai perajut antar partikel tanah. Pertumbuhan miselia fungi lebih efektif meningkatkan partikel tanah daripada mikroba yang kecil, seperti bakteri. Dengan adanya fungi yang bermiselia akan menyebabkan struktur tanah menjadi lebih baik.

Hasil pengamatan warna tanah menunjukkan bahwa pada pola rotasi N-P dan N-S memiliki warna tanah yang sama yaitu coklat kekuningan gelap sedangkan pada pola rotasi N-N didapatkan warna kuning kecoklatan. Warna gelap pada pola rotasi N-P dan $\mathrm{N}-\mathrm{S}$ didapatkan dari C-organik di pola rotasi N-P dan N-S lebih tinggi dibanding pola rotasi N-N. Jika pada N-P kandungan C-organik sebesar 1,22\% dan N-S sebesar 1,28\% maka pada pola rotasi $\mathrm{N}-\mathrm{N}$ hanya sebesar $0,69 \%$, hal tersebut sesuai dengan pendapat

Tabel 2. Struktur tanah pada pola rotasi nenas-pisang, nenas-nenas dan nenas singkong

\begin{tabular}{ccccc}
\hline No & Lokasi & Bentuk & Ukuran & Derajat \\
\hline 1 & N-P 1 & Granular & Sangat halus & Kuat \\
2 & N-P 2 & Granular & Halus & Kuat \\
3 & N-P 3 & Granular & Halus & Kuat \\
4 & N-P 4 & Granular & Sangat halus & Sedang \\
5 & N-P 5 & Granular & Halus & Kuat \\
\hline 6 & N-N 1 & Granular & Halus & Sedang \\
7 & N-N 2 & Gumpal membulat & Sedang & Kuat \\
8 & N-N 3 & Gumpal membulat & Sedang & Kuat \\
9 & N-N 4 & Granular & Sedang & Kuat \\
10 & N-N 5 & Gumpal membulat & Sedang & Kuat \\
\hline 11 & N-S 1 & Granular & Halus & Sedang \\
12 & N-S 2 & Granular & Halus & Kuat \\
13 & N-S 3 & Gumpal membulat & Sedang & Kuat \\
14 & N-S 4 & Granular & Halus & Kuat \\
15 & N-S 5 & Granular & Halus & Kuat \\
\hline Ked
\end{tabular}

Keterangan: $\mathrm{N}-\mathrm{P}=$ Pola rotasi tanaman nenas-pisang; $\mathrm{N}-\mathrm{N}=$ Pola rotasi tanaman nenasnenas; $\mathrm{N}-\mathrm{S}=$ Pola rotasi tanaman nenas-singkong

Hardjowigeno (2010) yang menyatakan semakin tua suatu warna tanah menunjukan makin tinggi pula kesuburannya, hal tersebut berhubungan dengan kandungan bahan organik didalamnya.Makin tinggi kandungan bahan organiknya, maka warna tanah akan semakin kelam. Sebaliknya, makin rendah kandungan bahan organiknya warna tanah akan tampak lebih terang.

Tabel 3. Warna tanah pada pola rotasi nenas - pisang, nenas - nenas dan nenas - singkong

\begin{tabular}{ccc}
\hline No & Perlakuan & Warna Tanah $($ Jeluk 0 - 40cm) \\
\hline 1 & $\mathrm{~N}-\mathrm{P}$ & $(10$ YR 4/2) Coklat kekuningan gelap \\
2 & $\mathrm{~N}-\mathrm{N}$ & $(10$ YR 3/3) Kuning kecoklatan \\
3 & $\mathrm{~N}-\mathrm{S}$ & $(10$ YR 4/2) Coklat kekuningan gelap \\
\hline Keterangan: & $\mathrm{N}-\mathrm{P}=$ Pola rotasi tanaman nenas-pisang; $\mathrm{N}-\mathrm{N}=$ Pola rotasi \\
& tanaman nenas-nenas; $\mathrm{N}-\mathrm{S}=$ Pola rotasi tanaman nenas-singkong
\end{tabular}


Nilai berat volume tanah, berat jenis tanah dan porositas tanah tersaji pada tabel 4 . Berat volume pada pola rotasi N-P dan N-S memiliki nilai yang hampir sama, nilai berat volume pada pola rotasi N-P dan N-S lebih rendah bila dibandingkan dengan pola rotasi $\mathrm{N}-\mathrm{N}$ yang menyebabkan rendahnya berat volume pada pola rotasi N-P dan N-S adalah pada pola rotasi N-P dan N-S mempunyai struktur yang lebih baik di banding pola rotasi N-N.Tabel 4. Berat Volume (BV), Berat Jenis (BJ) dan Porositas pada pola rotasi nenaspisang, nenas-nenas dan nenas-singkong. Struktur akan berpengaruh kepada berat volume, ketika struktur memiliki bentuk granular atau remah maka akan menunjukan BV rendah, selain itu kandungan C-organik pada pola rotasi N-P dan N-S lebih tinggi yaitu sebesar $1,33 \%$ dan $1,28 \%$ dan $\mathrm{N}-\mathrm{N}$ hanya sebesar $0,69 \%$ hal tersebut sesuai dengan pendapat Hanafiah (2007) yang menyatakan kandungan bahan organik yang tinggi pada tanah yang bertekstur geluh lempung pasiran membuat berat volume menjadi rendah.

Tabel 4. Berat Volume (BV), Berat Jenis (BJ) dan Porositas pada pola rotasi nenas-pisang, nenas-nenas dan nenas-singkong

\begin{tabular}{cccccc}
\hline & & \multicolumn{3}{c}{ Parameter } & \\
\cline { 3 - 5 } No & Perlakuan & BV & BJ & Porositas & Harkat Porositas \\
\cline { 3 - 4 } & & \multicolumn{2}{c}{$\mathrm{g} / \mathrm{cm}^{3}$} & $\%$ & \\
\hline 1 & $\mathrm{~N}-\mathrm{P}$ & $1,48 \mathrm{a}$ & $2,64 \mathrm{a}$ & $43,62 \mathrm{a}$ & Kurang baik \\
2 & $\mathrm{~N}-\mathrm{N}$ & $1,53 \mathrm{a}$ & $2,61 \mathrm{a}$ & $41,49 \mathrm{a}$ & Kurang baik \\
3 & $\mathrm{~N}-\mathrm{S}$ & $1,49 \mathrm{a}$ & $2,62 \mathrm{a}$ & $44,42 \mathrm{a}$ & Kurang baik \\
\hline
\end{tabular}

Keterangan: $\mathrm{N}-\mathrm{P}=$ Pola rotasi tanaman nenas-pisang; $\mathrm{N}-\mathrm{N}=$ Pola rotasi tanaman nenas-nenas; $\mathrm{N}-\mathrm{S}=$ Pola rotasi tanaman nenas-singkong. Hasil yang diikuti huruf yang sama dalam kolom yang sama menunjukan tidak ada beda nyata pada uji DMRT pada taraf $5 \%$.

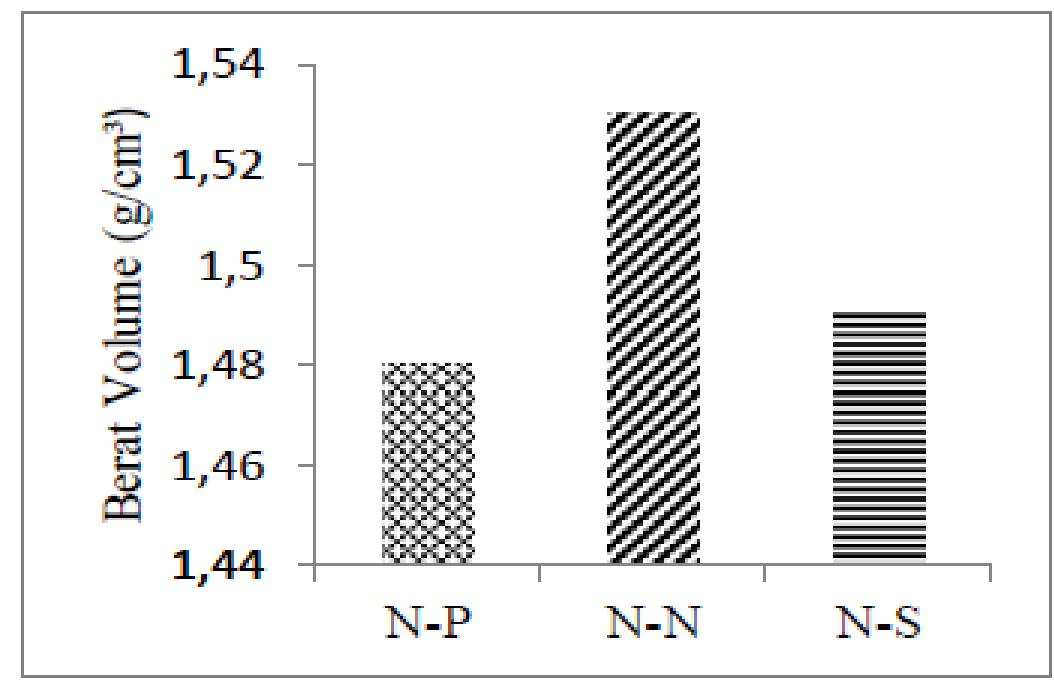

Gambar 1. Berat Volume pada pola rotasi N-P, N-N dan N-S 
Hal ini diakibatkan oleh tanah permukaan menjadi berbutir-butir dengan baiknya, butiran tersebut membuat keadaan menjadi longgar dan gumpalan sehingga berat volume menjadi rendah. Tingginya kandungan $\mathrm{C}$-organik akan mengundang mikroorganisme, dengan adanya aktifitas mikroorganisme di lokasi tersebut akan membuat tanah menjadi gembur dan nilai BV rendah. Pada ketiga pola rotasi yaitu N-P, N-N dan N-S ketiganya menunjukan harkat porositas kurang baik, hal tersebut berarti proporsi ruang pori yang berisi air dan udara tidak seimbang jika dilihat dari hasil retensi air dan tekstur tanah yang mendominasi adalah pori yang berisi udara. Walaupun ketiga pola rotasi tersebut memiliki harkat kurang baik tetapi nilai porositas lebih besar pola rotasi N-P dan N-S. Hal tersebut terjadi karena C-organik pada pola rotasi N-P dan N-S lebih besar dibanding pola rotasi $\mathrm{N}-\mathrm{N}$, dimana nilai C-organik pada pola rotasi $\mathrm{N}-\mathrm{P}$ sebesar $1,33 \%$ dan $\mathrm{N}-\mathrm{S}$ sebesar $1,28 \%$ sedangkan C-organik pada pola rotasi $\mathrm{N}-\mathrm{N}$ hanya sebesar $0,69 \%$. Hardjowigeno (2010) yang mengatakan porositas tanah dipengaruhi oleh kandungan dipengaruhi oleh kandungan bahan organik dan struktur tanahnya, porositas tinggi kalau bahan organik organik dan struktur tanahnya, tinggi. Kadar lengas tanah pada berbagai tegangan lengas pada berbagai rotasi tanaman (data tidak ditampilkan) dapat digambar kurva $\mathrm{pF}$. Tampak bahwa pada berbagai tipe rotasi tanaman, pola kurva karakteristik hampir sama, karena tekstur tanahnya juga hampir sama. Selanjutnya kurva karakteristik lengas tanah dapat digunakan untuk menentukan agihan ukuran pori yang ada di dalam tanah.

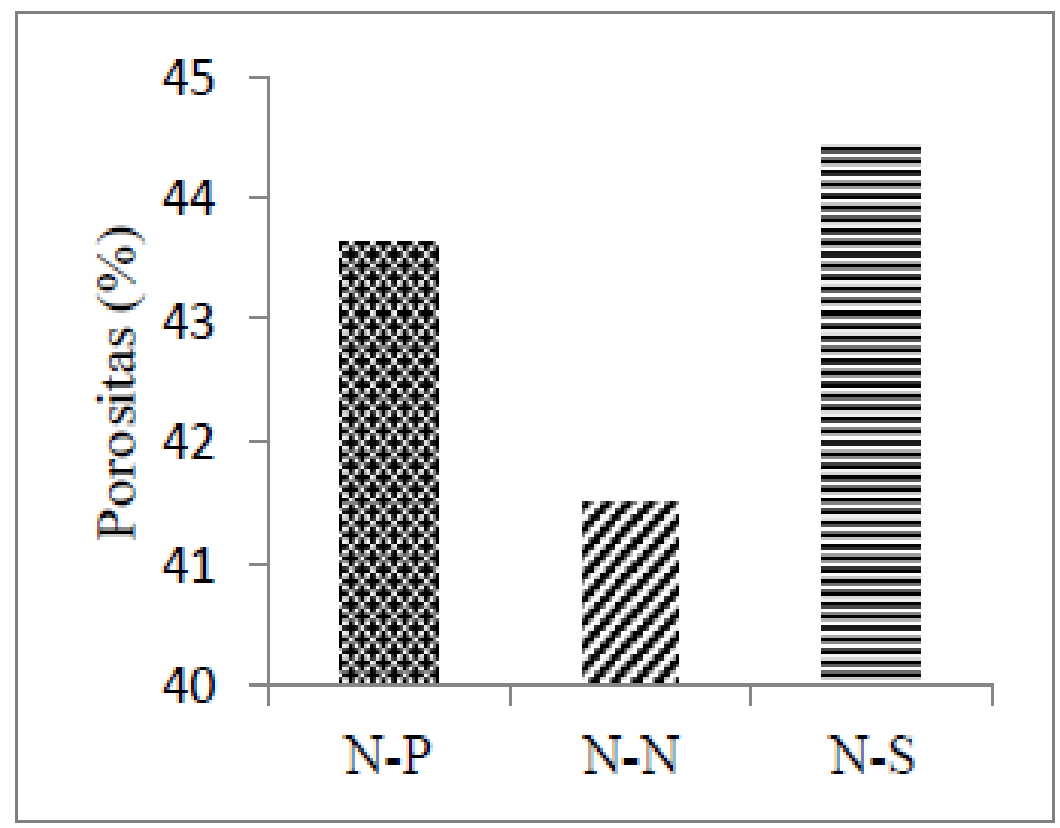

Gambar 2. Porositas pada pola rotasi N-P, N-N dan N-S

Agihan pori tanah menunjukkan kestrukturan dari tanahnya. Kelompok ukuran pori tersebut meliputi: Pori Drainase (PD) dan Pori Pemegang Air (PPA). Pori Drainase dibedakan menjadi Pori Drainase Cepat (PDC) dengan garis tengah pori terkecil 28,80 $\mu \mathrm{m}$ setara dengan $\mathrm{pF} 2$, dan Pori Drainase Lambat (PDL) dengan garis tengah pori antara $28,80 \mu \mathrm{m}-8,60 \mu \mathrm{m}$, setara dengan tegangan lengas antara $\mathrm{pF} 2-\mathrm{pF} 2,54$. Pori Pemegang Air mempunyai garis tengah antara $8,60 \mu \mathrm{m}-0,20 \mu \mathrm{m}$ atau pada tegangan lengas antara $\mathrm{pF} 2,54-\mathrm{pF} 4,20$ Tampak bahwa pola rotasi tanaman tidak berpengaruh nyata pada agihan pori tanahnya. Tidak menunjukkan adanya perubahan struktur tanahnya. Hal ini 
sejalan dengan permeabilitas tanah, salah satu tolok ukur kestrukturan tanah yang akan disampaikan selanjutnya. Harkat Pori Drainase (PD) lebih besar daripada Pori Penyimpan Air (PPA), artinya tanah mempunyai kemampuan besar membuang air dibandingkan dengan kemampuan menyimpan airmya. Besarnya fraksi pasir (lebih 50\%) menyebabkan jumlah pori makro lebih dominan dibandingkan dengan pori mikro. Kekuatan tanah, permeabilitas tanah (daya hantar hirolik jenuh) tersaji pada tabel 6. Presentase kekuatan tanah tertinggi terdapat pada pola rotasi $\mathrm{N}-\mathrm{N}$ dan yang terendah pada pola rotasi N-P, pada pola rotasi $\mathrm{N}-\mathrm{N}$ memilik nilai kekuatan tanah yang tinggi dibandingkan pola rotasi $\mathrm{N}-\mathrm{P}$ dan N-S hal tersebut karena pada pola rotasi N-N memiliki nilai BV yang lebih besar yaitu $1,53 \mathrm{~g} / \mathrm{cm} 3$ sehingga menggambarkan tanah lebih padat.Selain itu kandungan $\mathrm{C}$ organik (tabel selanjutnya) pada pola rotasi N-N lebih rendah jika dibandingkan pola rotasi N-P dan N-S.Jika pada pola rotasi N-N sebesar $0,60 \%$, pada pola rotasi N-P dan N$\mathrm{S}$ sebesar $1,33 \%$ dan 1,28\%. Seperti yang dijelaskan oleh Endrayani (2010) semakin tinggi bahan organik tanah menyebabkan berat volume semakin rendah dan porositas semakin tinggi sehingga menyebabkan penetrasi tanah pun menjadi menurun.

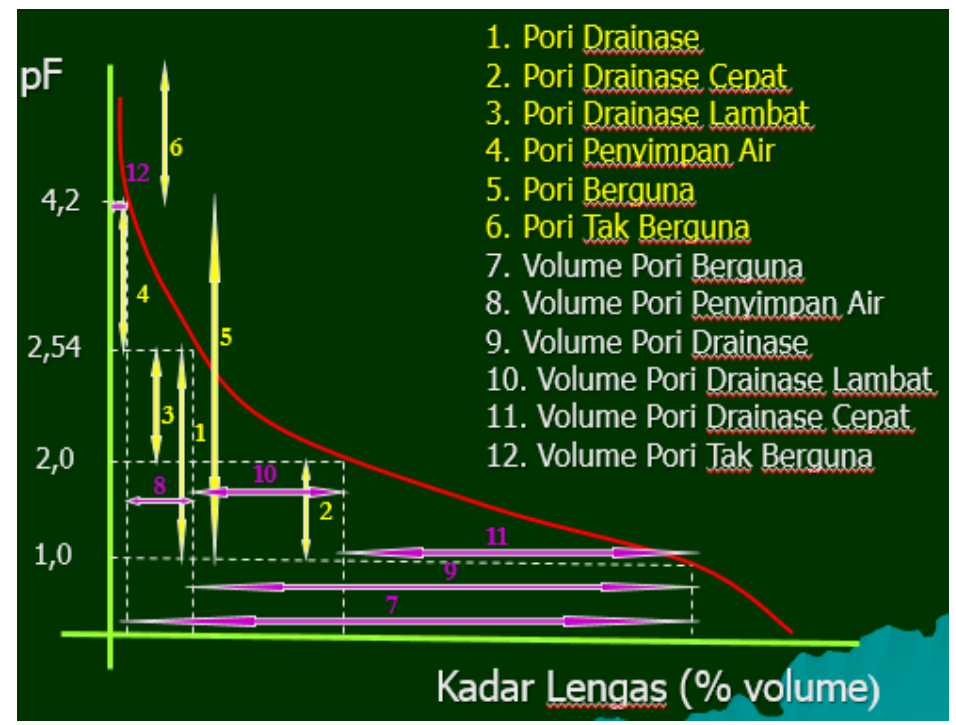

Gambar 4. Agihan pori tanah

Tabel 5. Pori Drainase Cepat (PDC), Pori Drainase Lambat (PDL) dan Pori Air Tersedia (PAT) pada pola rotasi nenas-pisang, nenas-nenas dan nenas-singkong

\begin{tabular}{|c|c|c|c|c|c|c|}
\hline \multirow{3}{*}{ No } & \multirow{3}{*}{ Perlakuan } & \multicolumn{5}{|c|}{ Parameter } \\
\hline & & \multirow{2}{*}{ PDC (\%) } & \multirow{2}{*}{ PDL (\%) } & \multirow{2}{*}{ PAT (\%) } & \multicolumn{2}{|c|}{ Harkat } \\
\hline & & & & & PD & PPA \\
\hline 1 & $\mathrm{~N}-\mathrm{P}$ & $21,45 \mathrm{a}$ & $1,05 \mathrm{~b}$ & $3,87 \mathrm{a}$ & Tinggi & Sangat rendah \\
\hline 2 & $\mathrm{~N}-\mathrm{N}$ & 20,68 a & $1,79 \mathrm{a}$ & $4,78 \mathrm{a}$ & Tinggi & Sangat rendah \\
\hline 3 & $\mathrm{~N}-\mathrm{S}$ & $22,37 \mathrm{a}$ & $1,37 \mathrm{ab}$ & $3,91 \mathrm{a}$ & Tinggi & Sangat rendah \\
\hline
\end{tabular}

Keterangan: $\mathrm{N}-\mathrm{P}=$ Pola rotasi tanaman nenas-pisang, $\mathrm{N}-\mathrm{N}=$ Pola rotasi tanaman nenas-nenas, $\mathrm{N}$ $\mathrm{S}=$ Pola rotasi tanaman nenas-singkong. Hasil yang diikuti huruf yang sama dalam kolom yang sama menunjukan tidak ada beda nyata pada uji DMRT pada taraf 5\%. 
Tabel 6. Kekuatan tanah dan permeabilitas pada pola rotasi nenas - pisang, nenas - nenas dan nenas - singkong

\begin{tabular}{ccccc}
\hline \multirow{2}{*}{ No } & Perlakuan & \multicolumn{3}{c}{ Parameter } \\
\cline { 3 - 4 } & & Kekuatan Tanah & Permeabilitas Tanah & $\begin{array}{c}\text { Harkat } \\
\text { Permeabilitas }\end{array}$ \\
\cline { 3 - 4 } & $\mathrm{Kg} / \mathbf{c m}^{2}$ & $\mathbf{c m} / \mathbf{j a m}$ & Agak lambat \\
2 & $\mathrm{~N}-\mathrm{P}$ & $0,78 \mathrm{a}$ & $1,17 \mathrm{a}$ & Lambat \\
3 & $\mathrm{~N}-\mathrm{N}$ & $1,22 \mathrm{a}$ & $0,50 \mathrm{a}$ & Agak lambat \\
\hline
\end{tabular}

Keterangan: $\mathrm{N}-\mathrm{P}=$ Pola rotasi tanaman nenas-pisang, $\mathrm{N}-\mathrm{N}=$ =Pola rotasi tanaman nenas-nenas, $\mathrm{N}$ $\mathrm{S}=$ Pola rotasi tanaman nenas-singkong. Hasil yang diikuti huruf yang sama dalam kolom yang sama menunjukan tidak ada beda nyata pada uji DMRT pada taraf $5 \%$.

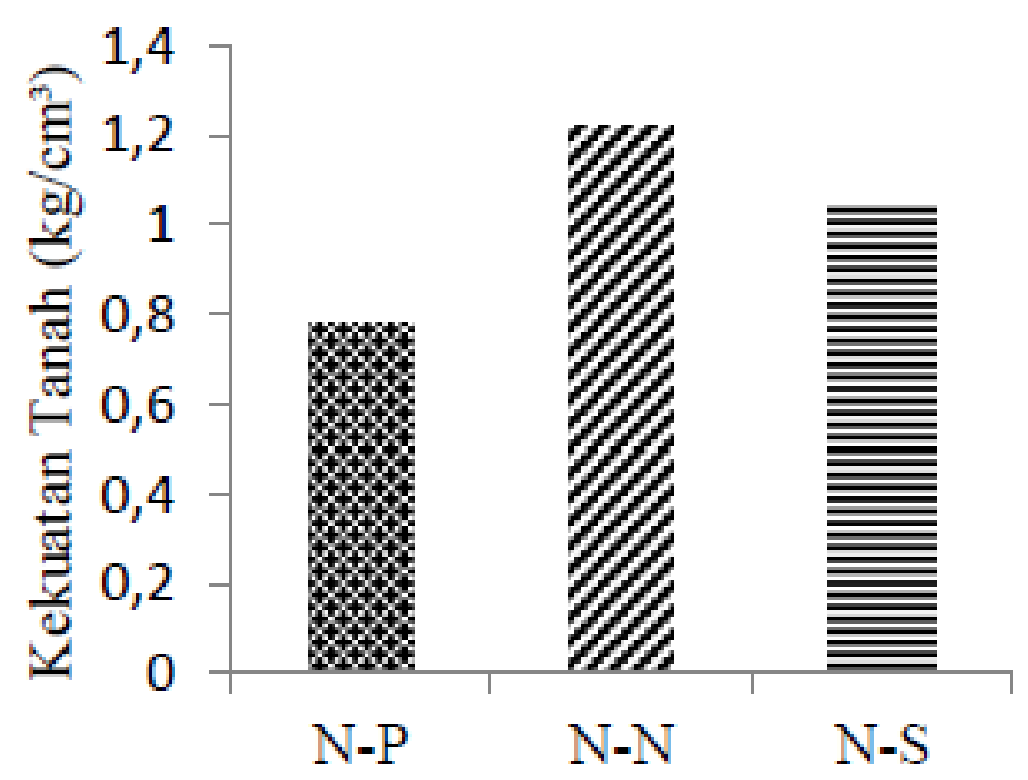

Gambar 5. Kekuatan tanah pada pola rotasi N-P, N-N dan N-S

Permeabilitas tanah pada pola rotasi N-N lebih lambat dibandingkan dengan pola rotasi N-P dan N-S. Hal ini ditunjukkan dengan lebih besarnya kekuatan tanah pada pola tersebut yang menunjukkan bahwa tanah lebih padat. Hal inilah yang menyebabkan kemampuan melewatkan airnya lebih kecil. Tampak bahwa kadar C organik tanah ultisol rendah. Hal ini memang umum dijumpai pada tanah tersebut. Pada pola rotasi N-N kadar $\mathrm{C}$ organik paling rendah, dibandingkan dengan pola rotasi N-P dan N-S. Hal ini terjadi karena pada pola rotasi N-P biomassa yang dikembalikan cukup besar 40 ton/ha sedangkan untuk pola rotasi N-S walaupun biomassa yang dikembalikan hanya 2 ton/ha tetapi sebelum ditanami singkong juga sudah mengalami pengembalian biomassa tanaman sebelumnya. Kenyataan ini diduga mempengaruhi beberapa sifat fisik tanah yang telah diulas sebelumnya. Kandungan N-total pada pola rotasi N-P memiliki harkat lebih tinggi dibandingkan dengan pola rotasi lainnya. Hal ini terjadi karena pada pola rotasi nenas - pisang lebih banyak bahan segar penyuplai nitrogen yang dikembalikan ke dalam tanah. Batang dan daun pisang kembali masuk ke dalam tanah, sedangkan pola rotasi lain lebih sedikit karena di bawa ke luar dari tanah. Rendahnya harkat N-total di 
lokasi penelitian karena pada PT. Great Giant Pineapple memiliki curah hujan yang tinggi sehingga banyak nitrogen mengalami pelindian. Tidak terjadi imobilisasi nitrogen di lokasi penelitian bila ditinjau dari nisbah C/N. Mikroorganisme dalam tanah relatif lebih mudah mendapatkan nitrogen karena tidak ada persaingan (Hanafiah, 2007).

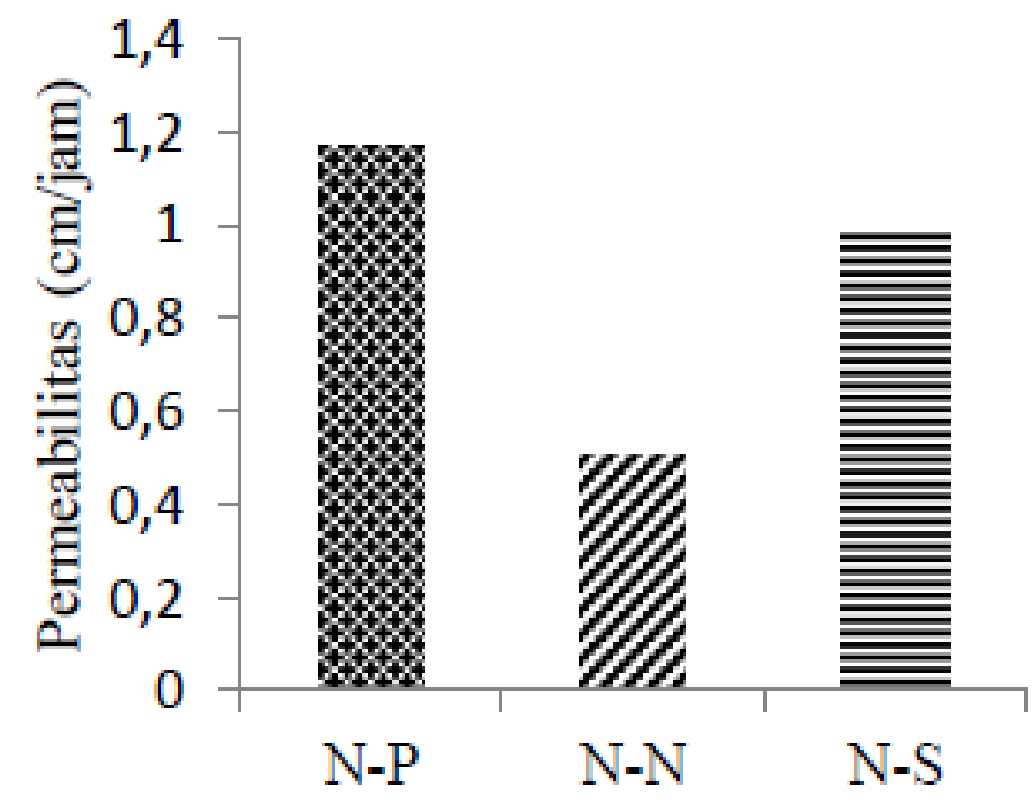

Gambar 6. Permeabilitas tanah pada pola rotasi N-P, N-N dan N-S

Tabel 7. $\mathrm{C}$ - organik, $\mathrm{N}$ - total dan Nisbah $\mathrm{C} / \mathrm{N}$ tanah pada pola rotasi nenas - pisang, nenas - nenas dan nenas - singkong

\begin{tabular}{|c|c|c|c|c|c|c|c|}
\hline \multirow[b]{2}{*}{ No } & \multirow[b]{2}{*}{ Perlakuan } & \multicolumn{6}{|c|}{ Parameter } \\
\hline & & $\begin{array}{c}\mathrm{C} \\
\text { organik }\end{array}$ & Harkat & $\begin{array}{c}\mathrm{N}- \\
\text { total }\end{array}$ & Harkat & $\mathbf{C} / \mathbf{N}$ & Harkat \\
\hline 1 & $\mathrm{~N}-\mathrm{P}$ & $1,33 \mathrm{a}$ & Rendah & $0,10 \mathrm{a}$ & $\begin{array}{c}\text { Sangat } \\
\text { tinggi }\end{array}$ & $12,33 \mathrm{a}$ & Sedang \\
\hline 2 & $\mathrm{~N}-\mathrm{N}$ & $0,69 \mathrm{~b}$ & $\begin{array}{l}\text { Sangat } \\
\text { rendah }\end{array}$ & $0,05 \mathrm{c}$ & $\begin{array}{l}\text { Sangat } \\
\text { rendah }\end{array}$ & $13,02 \mathrm{a}$ & Sedang \\
\hline 3 & $\mathrm{~N}-\mathrm{S}$ & $1,28 \mathrm{a}$ & Rendah & $0,08 \mathrm{~b}$ & $\begin{array}{l}\text { Sangat } \\
\text { rendah }\end{array}$ & $15,96 \mathrm{a}$ & Sedang \\
\hline
\end{tabular}

Keterangan: $\mathrm{N}-\mathrm{P}=$ Pola rotasi tanaman nenas-pisang, $\mathrm{N}-\mathrm{N}=$ Pola rotasi tanaman nenas-nenas, $\mathrm{N}$ $\mathrm{S}=$ Pola rotasi tanaman nenas-singkong. Hasil yang diikuti huruf yang sama dalam kolom yang sama menunjukan tidak ada beda nyata pada uji DMRT pada taraf 5\%.

\section{KESIMPULAN}

1. Pola rotasi yang terbaik adalah pola rotasi nenas-pisang dengan warna tanah coklat kekuningan gelap, struktur tanah dengan bentuk granular, ukuran sedang sampai halus dengan derajat kuat, nilai BV sebesar $1,48 \mathrm{~g} / \mathrm{cm}^{3}$, Pori drainase cepat dan pori drainase lambat dengan nilai pori drainase cepat $21,45 \%$ dan pori drainase lambat $1,37 \%$, Pada

2. Parameter kekuatan tanah, permeabilitas dan C-organik dengan nilai kekuatan tanah 
sebesar $0,78 \mathrm{~kg} / \mathrm{cm}^{2}$, permeabilitas dengan nilai $1,17 \mathrm{~cm} / \mathrm{jam}$ dan C-organik sebesar $1,33 \%$, untuk parameter $\mathrm{N}$-total dan Nisbah $\mathrm{C} / \mathrm{N}$ dengan nilai $\mathrm{N}$-total sebesar $0,10 \%$ dan C:N sebesar $12,33 \%$.

\section{DAFTAR PUSTAKA}

Arsyad, S., N. Sinukaban dan S. Sukmana. 1975. Fisika Tanah: Dasar-dasar sifat fisik dan proses. Proyek Peningkatan/Pengembangan Perguruan Tinggi. IPB. Bogor.

Endriani. 2010. Sifat fisika dan kadar air tanah Ultisol akibat penerapan sistem olah tanah konservasi. Jurnal Hidrolitan. Vol. 1.No. 1.Masyarakat Konservasi Tanah dan Air (MKTI) Cabang Jambi. Jambi.

Hanafiah, K., A. 2007. Dasar-dasar Ilmu Tanah. PT Raja Grafindo Persada.Jakarta. 360 hlm.

Hardjowigeno, S. 2010. Ilmu Tanah. Akademika Pressindo. Jakarta. 288 hal.

Suhastyo, A., A. 2011. Studi Mikrobiologi dan Sifat Kimia Mikroorganisme Local yang Digunakan pada Budidaya Padi Metode SRI (System of Rice Intensification). Tesis. Pascasarjana. Institut Pertanian Bogor.

Utomo, W., H. 1994. Kekerasan Tanah dan Serapan Fisik Tanah Syarat Mutlak Untuk Sistem Pertanian Terlanjutkan. Sains dan Teknologi. Gula Indonesia XIX (1): 9$13 \mathrm{hlm}$. 